\title{
Sharing and neoliberal discourse: The economic function of sharing in the digital on-demand economy
}

\begin{abstract}
In this paper I offer a critical analysis of 'sharing' as a discursive formation in the emerging on-demand economy or, as its more commonly known, 'sharing' economy. The set of firms and digital platforms that constitute the on-demand economy evade precise definition, though in popular commentary include Uber, Lyft, Airbnb, Taskrabbit, Couchsurfing, and Yelp, among others. I argue that sharing is a discursive formation that is produced through neoliberal economic practices and contributes to their constitution and performance, connoting the embeddedness and inter-determination of the economic with the social. I analyze interview material with software developers and others working for on-demand economy firms in San Francisco to underscore how the sharing discourse is produced, and to examine the possible relationship between the sharing discourse and working practices in the on-demand economy. I explore how sharing, though a fragile and contested discourse, has been used by some proponents of the on-demand economy in an attempt to justify and normalize flexible and precarious work through an ambiguous association between capitalist exchange and altruistic social values. This ambiguity is productive insofar as sharing has become associated variously with transactional platforms, digital peer review via surveillant and punitive ratings systems, and algorithmically mediated, precarious, and 'entrepreneurial' contract work, while retaining affective associations with community, inclusion, and participation.
\end{abstract}

Keywords: affect, digital media, discourse, on-demand economy, neoliberalism, sharing economy 


\section{Introduction}

The on-demand or 'sharing' economy is a term that describes digital platforms that connect consumers to a service or commodity through the use of a mobile application or website. ${ }^{1}$ Variously referred to as the gig economy (Gregg, 2015), platform economy (Schor, 2015), and collaborative commons (Rifkin, 2014), the on-demand economy defies a clearly agreed-upon definition, but usually refers to digital media firms that connect users through two-sided platform-based marketplaces. Early examples of ondemand platforms - including Couchsurfing, Craigslist, and Freecycle - provided not necessarily transactional services. ${ }^{2}$ Yet the most visible of these platforms now - Uber, Lyft, and AirBnB - promote by definition explicitly transactional user-interaction (Zervas et al., 2014) pointing to the inter-relationship and ambivalence between the social and economic character of these firms' platforms. These firms have been the topic of controversy for their intrusive impact upon existing transit, housing, and labor markets, while claiming their difference from these markets because of the digital context of their platforms and the rhetoric of sharing they deploy. Various other digital platforms have fallen under the sharing rubric of the on-demand banner, including short-term car rental services such as Zipcar; user-submitted ratings and review platforms such as Yelp; crowdfunding platforms such as Kickstarter; and impact, status, and reputation aggregators such as Traity.

That so many firms fall under the definition of the on-demand economy and therefore also the sharing rhetoric means that in order to make sense of their economic and social effects, close attention must be paid to their differences as a well as their similarities. These differences and similarities point to the complexities and paradoxes endemic to the sharing discourse itself. Indeed, some critical commentators have

\footnotetext{
${ }^{1}$ I use the term 'on-demand economy' synonymously with the more popular term 'sharing economy.' I do this so as not to reproduce the notion that the on-demand economy can be necessarily associated with sharing as such. Instead, I suggest that 'on-demand' better captures the tenor of these emerging digital and platform-based economic systems, while 'sharing' romanticizes broader normative transformations in flexible labor practices to which the ondemand economy contributes.

2 'Transactional' here refers specifically to monetary transactions. I see this definition as a necessary heuristic to describe differences between (1) platforms in which pecuniary exchange between users is endemic and essential to the use of the platform, and (2) platforms in which it is not. My intention is not to outline an arbitrary separation of the social and the economic, but to find a language to narrate the real differences between on-demand platforms.
} 
suggested that 'sharing economy' is itself a contradiction (John and Sützl, 2016; Sützl, 2014). Yet, I argue here that this contradiction is productive and does not render redundant the use of sharing to describe economic practice. As Richardson (2015, page 121) suggests, the central paradox of sharing in the on-demand economy is that performances of sharing are "framed both as part of the capitalist economy and as an alternative." Richardson asks us to view sharing as a complex articulation of economic activity that is iteratively performed rather than imposed on subjects from without, pointing to the ambivalences and ambiguities that characterize the use of terms like sharing to narrate economic practice. With writers like Zelizer (2005) I suggest the sharing discourse demonstrates the endemic intimacy of social and market relations, and though writers like Brown (2015) suggest that neoliberal forms of reason can be characterized as a transition from the former to the latter, I suggest instead that this presents too neat an image of capitalism in transition (McDowell and Dyson, 2011). The social and the economic have always existed in a relationship of intimacy and mutual constitution, and thus neoliberalism - if it is to remain a useful conceptual category - must be understood in terms of a new articulation of these emerging complex relationships to be examined, rather than as a totalizing and linear imposition of economic relations on an only passive social domain.

Yet the paradoxes and complex articulations of the performances of sharing vary by platform, suggesting different deployments of the sharing discourse, despite the apparent singularity of the 'sharing economy' moniker as mentioned above. For example, Couchsurfing is non-transactional, yet has been for-profit since 2011, and utilizes a revenue strategy based on advertising and user-interaction similar to social media sites (Cockayne, 2016; Fuchs, 2014). Transactional platforms like AirBnB and Uber both tout platforms that make available excess user 'resources' or 'assets,' yet Uber works on a model that employs users as contractors that allows them to sell their labor power to other smartphone users, while AirBnB users profit from listing properties, which does require work, but are not formally employed or remunerated by the platform. In each case therefore, questions quickly arise around precisely what is shared and with whom; how the sharing rhetoric is related (or not) to the revenue strategies of each on-demand firm; and whether sharing is the promise of a new community, a mask for the devaluation of 
labor under digital forms of capital, or some more ambiguous combination of both. Yet what is clear is that sharing, though still a contested and contradictory discourse, does connect a set of otherwise disparate economic practices and digital platforms, and the laboring subjectivities and affective dispositions that accompany them. What is required therefore, is close attention to how exponents of the on-demand economy encourage or dissuade, through the perpetuation of the sharing trope, particular and simultaneously laboring and social practices.

Here I examine the relationship between discourse and economic practice through the example of sharing rhetoric in the on-demand economy. I draw on interviews and participant observation with workers in San Francisco's digital media sector to examine the ambivalences and paradoxes of the sharing discourse. I conceptualize discourse as not incidental to economic practice, but instead as co-produced alongside it, and essential to capitalism itself (Marazzi, 2007). Here I view neoliberal capitalism as not only an exploitative system but also one that is also affective, in which attachment, intimacy, and identification are endemic to the mode of production (Berlant, 2011; Konings, 2015). The sharing discourse has a real function in the on-demand economy, and by drawing attention to how on-demand platforms do or do not promise community, inclusion, and participation through the sharing rhetoric, I demonstrate that language and economic practice are interrelated, and in doing so, contribute to an emerging affective geography of neoliberalism (Anderson, 2015; Cairnes, 2013; Joseph, 2014). I question in particular whether the production of sharing as a discursive frame for the on-demand economy is a concerted strategy that contributes to the flexibilization and de- or under-valuation of labor in the context of both changing work practices and ethics (Christopherson, 2002; Peck, 1992; 2002; Weeks, 2011) and digital forms of labor that are often characterized by their encouragement of piece-work, labor fragmentation, and un- or under-payment (Irani, 2015; Lehvonditra, 2016). I argue in this light that sharing as a discursive formation is not incidental to economic practice, but instead contributes to its very constitution and performance.

In the next section I present a conceptual framework for thinking through sharing in the on-demand economy, examining approaches in cultural economic geography, literatures on neoliberalism and its relationship to discourse, and research on sharing 
specifically in the context of digital and social media. In section three I briefly discuss the methodology employed to collect the data I present in the section that follows. In section four I present evidence from interviews and participant observation with entrepreneurs and software developers working for on-demand economy firms in San Francisco to think through first the contested and contradictory set of meanings that accompany the sharing discourse, second the unanimous association of sharing with purportedly egalitarian peerreview systems, and third, the images research subjects presented on how sharing as an affective promise that would change social relations. In this section I reflect on the relationship between the narration of sharing as an economic practice, and the implications for laboring relations in the on-demand economy.

\section{Economic discourse, neoliberalism, and digital sharing}

"Discourse is not simply that which translates struggles or systems of domination, but is the thing for which and by which there is struggle, discourse is the power which is to be seized" (Foucault, 1981, page 52-53).

Researchers in the cultural economic tradition in economic geography have consistently argued that the economy is constitutively interwoven with other notspecifically economic phenomena (Ettlinger, 2003; Gibson-Graham, 1996; McDowell, 1997; Shoenberger, 1997). Drawing on economic sociology, geographers have emphasized the always-embedded character of economic processes, and that the function of markets is constructed in conjunction with social conditions (Lawson, 2010; Peck, 2005). Cultural economic geographers argue that the expectations of certain working conditions over others (i.e., that jobs is permanent or transitory, that one can or should attempt to climb the corporate 'ladder,' etc.) are themselves constructed and produced, and are not the natural product of a transcendent and singular market system. For example, contract work in creative industries tends to be framed positively yet condescendingly as available, flexible, and fun work (often in direct contradiction with the material conditions of that work) that could neatly fit into the lives of any individual to earn them a little extra pocket money (Christopherson, 2008; McDowell, 1997). This 'flexibility' is presumed to be desired by and desirable for the worker. The classification (legal or otherwise) of work as contracted, part-time, temporary, flexible, and so on characteristics often associated with post-Fordist and neoliberal working conditions (Gill 
and Pratt, 2008) - has considerable ramifications for how work itself is understood. Thus, precisely how the capitalist-consumer views work and objectifies workers is mediated in and produced through discourse, among a variety other factors (Neo, 2010).

The production of discourse alongside economic practice, as noted in the quote by Foucault (see also 1972; 1978) above, is a site of negotiation, resistance, and struggle. Discourse is not constructed from above by a capitalist class and unilaterally imposed upon a passive workforce (Massey, 2004). Nor is it the linear and predictable result of sets of identity categories or classed positions. Discourse describes sets of linguistic statements, constitutive silences, and material practices that are held together through their iterative performance and reinforced through their doing (Butler, 1990), not by their reference to an external or a priori essence. Thus, though work may be constructed through particular discursive frames, workers and other subjects may reject or reify those frames in dynamic and unpredictable ways that do not necessarily neatly reflect their personal circumstances or characteristics. This points to the relationship between language and economic practice - the way that we talk about and discuss work relates directly to how that work is valued, and contributes to the reproduction or attrition of the idea that, as Weeks (2011) argues, work is a natural and uncontestable facet of social life. By emphasizing how firms in the on-demand economy narrate work as a form of 'sharing,' we can construct a much needed account of how flexible or precarious work in this case is normalized, reproduced, and even romanticized by those firms and platforms (Peck, 1992), and how firms form strategies that seek to naturalize and reify flexible and precarious circumstances as ethically appropriate for contract and other workers (Coe, 2013; Gill and Pratt, 2008; McDowell and Christopherson, 2009; Waite, 2009). These working discourses intersect with adjacent discourses around technology, since the political economic is increasingly mediated by digital systems (Leszczynski, 2012). Ondemand economy firms reframe sharing in terms of transactional exchange and convenience for the consumer, justified in part through more general technological tropes of openness, transparency, novelty, and disruption that frame sharing as an altruistic and non-reciprocal social interaction (Ettlinger, 2014; Hacklay, 2013; Turner, 2006).

As others have argued, neoliberalism as a concept has become so capacious as to be of almost questionable conceptual value (Barnett, 2005; Castree, 2006). Yet from the 
point of view of cultural economic analyses, neoliberalism cannot be conceptualized as a singular phenomenon constituted by only-economic processes, but as a complex and incomplete process that is produced by contradictory forces constituted through both economic practice and discourse (Brown, 2015). This is a useful framework because it implies neither that the economy is somehow privileged over or distinct from the noneconomic, nor that neoliberalism is a hegemonic system to which we are irretrievably and inevitably subject. Neoliberalism as a concept cannot simply reproduce what was saliently critiqued of globalization narratives, by serving as totalizing or capitalocentric, and positioned as a neutral or inevitable moment in an only capitalist Western history (Gibson-Graham, 1996; Larner, 2003; Larner and Walters, 2004). Instead, neoliberal reason can be thought as a contested, fragile, and incomplete discursive and linguistic system that is "disunified and nonidentical with itself in space and time," (Brown, 2015, page 21; see also Foucault, 2008), and conceptualized as excessive of (yet without ignoring) mobile urban and domestic economic policy (Harvey, 2005; Peck, 2004; Peck and Tickell, 2003; Ong, 2007).

In the context of social media use sharing discourses represent close correspondences with sharing in the context of the sometimes-transactional on-demand economy, and has been described as a 'fuzzy object' (John, 2012) or a form of 'pseudosharing' (Belk, 2014a; 2014b) based upon a 'fundamental contradiction' that can be connected up with neoliberal logics (Banning, 2016). This contradiction is productive, pointing to the transition in meaning sharing has undergone in the digital context, from a predominantly social use to one associated directly with the revenue strategies of social media firms, while retaining connotations with the affective feeling of inclusion promised by online engagement and romanticized forms of community (Joseph, 2002). Benkler's (2004; 2006) work attests to this shift, romanticizing sharing practices as essentially altruistic, pro-social, and non-reciprocal, yet predicated too on private ownership and the possibility of capitalist exchange. In the context of sharing content on social media platforms, 'to share' is used intransitively, without an object, as a partial statement, demand, or injunction (John, 2013). This demand made of users to 'share' content relates directly to social media platforms' revenue strategies, since data contributed by users are packaged, sorted, collated, and made available as products sold to advertising and 
marketing firms (Fuchs, 2014). Sharing describes both a form of digital production and inclusion in an online 'community' (Grabher and Ibert, 2014; Leyshon, 2007), yet is still connected linguistically with Benkler's altruistic, pro-social, and democratic associations of the sharing discourse that directly appropriates forms of behavior online as codependent, therapeutic, and confessional (John, 2013). Social media therefore intimately connects sharing with exchange, transaction, and economic production, but also uses the term to promise of new forms of digital belonging and inclusion. As noted in the introduction, sharing in this context is constructed both as capitalist production and exchange, and its alternative (Richardson, 2015).

The ubiquity and reproducibility of 'shared' information online, the negligible value of this information, and the supposed altruism of contribution is central to the economic structure of digital systems. Banning (2016) uses the term 'info-liberalism' to point out the connections between neoliberal capitalism and digital communication. In the context of social media, she argues that sharing is used to form an affective link between user-participation and the accrual of revenue through the repetition of positive associations between contribution and community. Banning (2016, page 490) argues that "sharing is yet another avenue through which the ordinary, everyday labor is affectively woven into neoliberal capitalism." I extend this argument in the next sections to outline sharing as an affective injunction, one that cannot be limited the description of the extraction of surplus-value from unremunerated social media uses (Fuchs, 2010) but that also extends to sharing as used by on-demand firms. Information shared on social media by individual users has almost no value, a characteristic connected to its excessive, ubiquitous, and easily reproducible qualities. Connecting the sharing of information online to sharing in the context of the on-demand economy therefore risks conflating labor - remunerated or unremunerated - with this contribution of nearly valueless information. Following Banning's argument therefore, I explore through the presentation and analysis of empirical material from fieldwork, whether sharing in the on-demand context can be conceptualized as an attempt to normalize flexible forms of work by positing labor as an expected and demanded contribution, an abundant and almost valueless pre-requisite for inclusion, in which sharing is related to the repetition of affect that promises social status through economic participation, rather than participation on 
social media platforms.

Sharing as a rhetorical trope that promises inclusivity in the context of the ondemand economy risks an association with the sale of one's labor-power, rather than the gifting of one's content on social media platforms. This compounds the paradox of sharing as both an extension of capitalist economies and their alternative. Laboring, or sharing bodies may be attuned to an entrepreneurial mode of flexible work in which the consumer views labor, borrowing from the intransitive sharing demand particular to social media use, as little more than an informational, abundant, reproducible, 'bit' (Brown, 2015) or 'dividual' (Deleuze, 1992) of human capital. As I explore, if labor can be understood in these terms, in correspondence with the demand to share content or information in the social media context, it is devalued and viewed only as an infinitely available commodity for on-demand purchase with barely any value. This labor may become taken-for-granted and made into an expendable object through terms set by ondemand firms through the sharing discourse and the whims of smart-phone users to nullify the distinction between digital commodities and labor-power. In this context, withholding one's labor (or the 'gift' of one's shared contribution) would be viewed as a petulant or selfish rejection of the promised post-capitalist community and better goodlife (Ahmed, 2010; Berlant, 2011). Consumers expect compliance from labor as they would from commodities, and enforce these normative standards through practices of peer-enforced 'soft-control' mediated through the platform.

In the sections that follow I examine the extent to which workers for firms in the on-demand economy use the sharing trope as an attempt, whether successful or not, to frame labor in the terms outlined above. Interviewees had diverse opinions about what sharing meant, and whether transactional firms could be included in the definition of 'sharing' in the on-demand economy. Speaking to the fragility and constructed quality of discourse, sharing emerged as a contradictory and contested term, and one whose definitive meaning had not been fully realized, especially given the variety of firms collected under the sharing rubric. Yet, I also suggest that ambivalence, contradiction, and paradox, seemingly endemic to the use of sharing in the on-demand economy are productive insofar as, uncertainly and haltingly, subjects often associated transactional accounts of sharing in the on-demand economy with the pro-social, altruistic, and 
inclusive of broader, non-transactional definitions of sharing. Before I present and discuss this empirical material, I will briefly outline the methods used.

\section{Methodology}

The material presented here is the result of eighteen months of fieldwork with workers in San Francisco's digital media sector. I conducted interviews with forty-five individuals, and participant observation at networking and conference events. Participants were recruited at said events, as well as through respondent-driven sampling (Gile and Handcock, 2010). Though the fieldwork was not focused exclusively on the on-demand economy, participants represented twenty-five on-demand economy firms as per the broad definition given in the introduction. Almost all interviewees worked for small firms of fewer than ten employees, though some worked for medium sized and more established firms with fewer then one hundred employees. One worked as a senior developer for a large, established, and internationally recognized ridesharing firm, while two others worked for firms that consisting of only a single employee (i.e., themselves). In many cases I interviewed founders or co-founders working at the firm since its inception. Interviewees thus had significant degrees of seniority and control over their firm. Interviewees lived and worked in the Bay Area, mostly in San Francisco, and as such, though I did not ask questions directly about income, they thus had the means to afford rent in San Francisco or the surrounding areas or alternative support that allowed them to alleviate that cost. All interviewees gave the appearance of being relatively privileged, affluent, and educated.

Interviewees cited here represented a variety of roles in their firms; they were technical and non-technical entrepreneurs, front and back-end software developers (including lead and junior developers), UX designers, and senior operations officers. Especially in the case of the smallest firms, these roles overlapped substantially. Interviewees did not just represent one kind of firm, which might result in a biased set of perspectives on sharing in the on-demand economy. To capture a range of perspectives the firms sampled included for-profit but non-transactional firms like Couchsurfing, quasi-transactional firms that provide a platform for monetary and non-monetary exchanges like Freecycle, firms like Uber that were explicitly transactional and depended 
on contract labor, and firms like Airbnb that while connoting substantial amounts of work for hosts and were explicitly transactional, did not contract laborers directly.

Interviews were semi-structured, conversational in tone, and were conceptualized as a negotiated experience constructed collaboratively between interviewer and participant (McDowell, 2009; Sin 2003). Early in each interview and prior to direct discussions of sharing, I asked all participants, "what's the concept behind you firm's platform?," which gave participants the opportunity to talk through the product that their firm was designing. In response to this question, interviewees often pre-empted the later more explicit discussion of sharing by linking their firm's concept or product to sharing discourses. In their response to this question, many interviewees and not just those working for on-demand firms drew on the sharing trope as a generic reference to digital media and to how they saw their firm contributing to a social as well as economic good. Following this question, I asked participants more directly about the sharing discourse, with questions like, "would you say that you firm is part of 'the sharing economy?'," "what do you think of the term 'the sharing economy?'," and follow-up questions like "do you see your firm's platform as similar or different to other platforms under the definition of "the sharing economy?"' In the empirical section that follows, interview subjects are assigned pseudonyms and relevant, but non-identifying information (in order to protect their anonymity), is included where necessary.

\section{Sharing work, sharing as work}

Here I present material from interviews with entrepreneurs, software developers, and others working for on-demand firms in San Francisco to explore how they contribute to the production of the sharing discourse, and what they understand that discourse to mean and do. First I describe how subjects narrated their contention or identification with sharing, outlining the productive contestation and contradiction that characterized subjects' exposition of the discourse. These accounts connote the productive character of sharing insofar as it created ambivalence between the purported altruism of nontransactional platforms, and the capitalist impulse of transactional platforms, thus allowing the latter to be aligned with characteristics of the former through the sharing discourse and rhetoric. Second, I explore the implications of subjects' agreement that 
sharing required the creation of trust between users through ratings and review systems. Finally, I discuss how subjects narrated their attachment to or fears for a future for the on-demand economy figured through the sharing discourse as an affective and often romanticized promise. Subjects presented an image of sharing that is complex, but not hegemonic, totalizing, or wholesale. This points to the still-contested character of the relationship between sharing in the on-demand economy, which is above all halting, hesitant, incomplete, and marked by fragility, yet, as I argue, with real effects for the ondemand platforms' users, and with potentially negative effects for platforms' contracted and other workers.

\subsection{Narrating 'sharing' in the on-demand economy}

Interviewees had a number of perspectives on the sharing discourse, what it did, and for whom it was beneficial. Opinions differed between those working for nontransactional and transactional platforms, turning around precisely what sharing meant, and whether transactional platforms could 'truly' be described through the sharing discourse or not. Interviewees often downplayed the laboring content of contractor and other forms of work in the on-demand economy, focusing instead on romanticized characteristics of sharing in terms of building out a network, participation, inclusion, and as a site for mutually beneficial interactions between strangers. I argue that the ambivalence between non-transactional and transactional examples of sharing is productive in that is allows the latter to be associated with some of the positive characteristics of the former, however haltingly and uncertainly. Despite the diversity of opinions I present here, as I discuss in the next section, all subjects, whether working for transactional or non-transactional firms emphasized the importance of trust in the sharing economy and were anxious to quantify user interaction in the form of user ratings and review systems.

Michelle who worked for a transactional firm noted the appeal of sharing in the on-demand economy. "I think it's great," she said, "that was part of attracted me actually

\footnotetext{
${ }^{3}$ Since each interviewee's anonymity is guaranteed, and the firms discussed are often small, stating the name of each firm could disclose the identity of the interviewee. I provide important and relevant details about the firms in question. In the context of Michelle's statements, it is
} 
to joining [this firm], you saw what was going on with Airbnb [...] and so the idea that, yeah, we don't have tons of resources, how can you make better use of them?" For Michelle, sharing was an issue of scarcity, making resources available, and making better use of them. She continued,

"[these resources] are a prime example, they are used fourteen days a year that's a lot of days not being used, so we actually think it is one of the better used cases of the sharing economy. Versus sharing your drill or things like that which are much lower dollar items, yeah it costs $\$ 150$ to buy one, and yeah you're only using it for fourteen minutes [sic] a year, but it's a lot of bother to go and borrow someone else's, pay them for it and then drop it back off. So you're time is also worth something."

Eric, working for a transactional ridesharing firm, stated "it does carry that positive connotation of being progressive. And [...] it sort of imbues this sense of, everyone being able to play a part. Which maybe I'm actually... I probably tend towards socialism at heart, I think that's probably a part of it for me." Michelle and Eric explicitly affiliated sharing with altruism, community, universality, more equitable access to resources, and even socialism, yet in the context of private ownership, transaction, and payment, and, in terms of the latter's statement, the sale and purchase of labor power. Michelle implied that the value (or virtue) of sharing is directly proportional to both the dollar value of the resource shared and the amount of time those resources would otherwise go unused by their owner. Sharing in this understanding meant making better use of one's possessions (framed as 'resources') at a cost to others. The 'amount' of sharing was based on the monetary value of the item and infrequency of its use. In transactional definitions of sharing like this one, the 'value' of the item shared, measured in dollars thus attained for this interviewee the status of equivalence with the relative of virtuousness of the sharing act, rendering clear distinctions between 'resources' and 'labor-time' lost.

Yet not all research subjects subscribed to this easy synonymy between an altruistic description of sharing and transactional platforms. Amanda, describing her opinion on the difference between her for-profit, non-transactional firm and Uber stated,

"you know, [Uber] is a company that makes money, with drivers that make money, there's transactions happening, and it's not like the person who's getting the ride is giving them anything other than cash. So I take issue with the sharing

important to note that the resources her firm make available are high-dollar value luxury items, and that the cost of direct ownership, upkeep, and insurance would out-price most consumers. 
economy. There are companies that I think have the right thing at heart which is why [my firm] as a non-profit, ${ }^{4}$ its history, its community, the people that built it, have all worked toward something together, and I think we are just continuing that vision."

Similarly, Mike, working for a for-profit, quasi-transactional firm ${ }^{5}$ stated,

"I mean I think there's some similarities, but would say [my firm] is in the more traditional sharing economy of like you share goods, or you trade with another person, whereas maybe Uber is a little bit more abstracted, or distantly related. There are some of these services, its more like a taxi service, less... more like ondemand."

These subjects suggested that their non-transactional firms could be more appropriately described as 'sharing' firms and attempted to distance the deployment of sharing in terms of their firms and work from more explicitly transactional firms like Uber. Amanda stated explicitly that she felt that the pecuniary character of some on-demand platforms precluded their participation in the sharing discourse. While apparently rejecting transactional accounts of sharing, both Amanda and Mike appealed to a sentimental definition of sharing based on community, togetherness, or traditionalism, yet also worked for explicitly for-profit platforms that based revenue strategies on the solicitation of unpaid contributions from users - the digital definitions of sharing in the context of social media use outlined in section two - and managed those user-interactions through ratings and review systems to build trust between users.

Sophie, further associating sharing with altruism and community stated,

"we are only at the tip of a sharing economy where we deal, at least three times, we do transactions three times a day with strangers, completely strangers. You just jump in an Uber pool, and sit next to the other person, you have no way of knowing what kind of person do you have in front of you."

Evacuating the laboring content from ridesharing platforms as others had above, Sophie defined sharing socially as an encounter between strangers rather than as an exchange of labor-power or resources. By deflecting attention away from the purchase of labor-power, she framed the on-demand economy as a predominantly social, trusting, and reciprocal encounter between strangers. She associated sharing in the context of her own firm's

\footnotetext{
${ }^{4}$ This interviewee's firm was in fact not a non-profit at the time of the interview or since.

${ }^{5}$ This participant worked for a firm that dealt with platform-specific credits that could be exchanged for goods. Users could procure additional credits through a variety of means, including real-money transactions, though real-money transactions were not strictly essential to the firm's procurement of revenue.
} 
platform, a digital reputation aggregator, with a promise she attributed to new technology in general, indicative of what she described as "hyper-democracy and heroism," in which, "you do not need to reach fame or power in order to create a positive impact in your world [...] you could do something good and actually your impact is measurable." Sharing for Sophie connoted a positive social space of inclusion and community between people that are "completely strangers," people who are invited into a car, or into someone's residential space, without full knowledge of who the other occupants are or what they intend.

Another interviewee, David, framed the sale of labor-power in the context of ridesharing firms as a form of participation, again directing attention away from the explicitly economic context of transaction to also conceptualize sharing as a space of uncertainty and encounter between strangers. He said that as a driver sharing meant,

"a space where you could run into anyone, and especially with [this platform] because the person is incentivized to sit in the front seat, [...] it's really, I think it's a really good space [...] and I could get exposed to different people, because even with sharing economy, in terms of specifically rideshare, it breaks social barriers."

David emphasized the reciprocal and conversational character of the sharing spaces that ridesharing creates, "there's a benefit to both of us," he said, "you've never met before so you're learning new stuff, you'll probably never meet again, so they could tell you anything." The ephemerality of the space of shared experience in this account "breaks social barriers" through the short-term character of the relationship, and the absence of obligation between parties. Sharing, as a space of private exchange and reciprocation creates a temporary impersonal (yet intimate and proximate) space of anonymity, impunity, and non-obligation. David, as others did above, downplayed the economic component of on-demand platforms and sharing was associated for him more with the expectation of a particular affective space (also constitutive of particularly disciplined kinds of behavior) experienced by those soliciting services through on-demand platforms.

In these accounts, subjects associated sharing with a shared space, something coconstituted and encountered together, though subjects had differing opinions on whether transactional spaces could truly be described in terms of the sharing rhetoric. Yet, this ambiguity was productive insofar as it allowed those firms with transactional platforms to be associated (whether definitively or not) with the presumed altruism of non- 
transactional on-demand platforms. This generative ambivalence between the economic, laboring, and the social aspects of the sharing practice in some cases rendered individual labor-power subordinate to, though still constitutive of, consumption in the on-demand economy.

\subsection{The "reciprocity principle," or, the production of trust through user-ratings and reviews}

While a key value of sharing in the above section was the constitution of a barelyeconomic social space of encounter between strangers in the on-demand economy, these spaces simultaneously created a problem since they also connoted a shared risk between parties. The question of how to manufacture trust between otherwise unknown users, in the absence of the possibility for face-to-face transactions - often described as essential to economic interaction (Bethelt and Turi, 2011; Storper and Venables, 2004) - emerged as necessary and constitutive to definitions of sharing for all firms and their platforms, whether they were transactional and non-transactional (Murphy, 2006). At networking events, the mitigation of risk and production of trust were the most frequently discussed topics and were viewed as issues uniting different proponents of the sharing economy, irrespective of their platform's respective functions. Yet the necessity for security and trust between users paradoxically created, on the one hand, the perception of equality between parties (that one interviewee called a "reciprocity principle") but, on the other, an uneven and punitive system in which labor and other forms of participation in ondemand platforms was controlled and instrumentalized through compulsory algorithmic management such an user-ratings and reviews.

On the point of the production of trust as an egalitarian system between parties, Eric, commenting on the ride-sharing platform his firm had designed, stated

"people can rate the drivers and the drivers rate the passengers. Drivers rate the riders, and that's a very important thing, it's not only do you get that peer review, and you get that rating to ensure that you're a good actor in the system, but it also actually changes your behavior as a person, as a consumer. It's like a reciprocity principle."

He continued, "the system largely works on the concept of trust and on the concept of reviews from other people, right, so it's like peer review for you as a person." Similarly, Mike asserted, "when you build a marketplace you have to build trust," he said, "if I sign 
up for it I need to trust [the platform] as well as its other members, to actually ship everything, and to make sure it's not going to steal my money, and that you know, that it's actually reliable." The need for trust in the platform (and marketplaces in general) was framed variously and positively as a "reciprocity principle" that connoted a relationship of equality between parties (since drivers and passengers both had to rate one another) in the mutual production of trust, as a way to prevent theft and 'protect consumers.' Though interviewees implied that trust was an expectation experienced equally between parties, it functioned additionally (hinted at in the accounts above) as a means of imposing discipline and economic control over user behavior, in particular contract workers for ridesharing platforms or hosts on micro-rental platforms, through data-driven calculation and the attempt to eliminate risk (Amoore, 2011; CheneyLippold, 2011). Manufacturing trust and security, primarily through imposing systems that quantify individual conduct, appeared as a necessity across on-demand platforms and was described as a prerequisite for the capacity to share in each context.

In these cases, sharing was framed as a form of 'reciprocity,' which meant that rating one another's performance and interactions is framed as central to sharing practices in on-demand platforms, connoting paradoxically an equality between different kinds of users (e.g., drivers and passengers) and the careful identification and subsequent exclusion of those who aren't "good actor[s] in the system." For contracted drivers and users, responding to ratings and review systems means orienting one's behavior so that it aligned with values of the platform and its users. By transferring oversight to algorithmically mediated, user- and driver-led peer-review system, users, on a "reciprocity principle" of sharing based on allegedly equal participation and contribution, were asked to observe and inform on one another's behavior. Though interviewees in the above paragraphs framed review systems as mutual, egalitarian, open, and reciprocal, the burden of being a "good actor," and "changing behavior," as I go on to explore, fell unevenly on certain users such as the contracted driver in the case of ridesharing platforms.

David too noted this uneven expectation between driver and passenger who said, commenting on ridesharing platforms, "the first two weeks of being a driver are really hard, because [...] they have this ratings system, [...] if you fall under 4.6 [out of 5] you 
get a message saying you need to buck up, and if you don't you get booted off." He noted the punitive characteristics of these ratings systems, "especially in the Bay Area," he said, "with reviews on anything, people go, they're really harsh on ratings." Review systems connoted the orientation of particular kinds of worker behavior into alignment with the expectations of the platform and its users, instead of the interests of the worker. Since, "you may not be familiar with the area, you may be too nervous to talk to people, whatever, you may not know how to pick people up," David emphasized how review systems as disciplinary, and enforced the 'right way' of being a "good actor" (in Eric's normative phrasing above) for the platform by ensuring that all drivers had an appropriate familiarity with the area, an appropriate disposition, and knew how to pick people up 'correctly,' without the platform having to intervene directly. Review systems enforce a particular affective attitude from drivers who cannot be "too nervous," but must instead perform for their passengers an appropriate degree of confidence and enthusiasm for their precarious economic circumstances. Review systems quickly eliminate people deemed inadequate by drive (with no opportunity for drivers to contest ratings) and serve as a corrective technique for anybody unsure about how to behave or act as a driver.

Subjects confirmed the effects of these ratings and review systems both in terms of the economic control on-demand ridesharing platforms have over drivers, and in terms of letting people go without the opportunity for appeal or contestation. Commenting further on this, David continued,

"they tell you who to pick up, they tell you when you can't ride for them anymore, you know, you have to accept a certain amount [of rides], they tell you a lot of things you have to do, it doesn't sound like too much like a contractor to me, it sounds like a loophole. [...] They have complete economic control over you. There are certain times when you make more money, so you're gonna work that time, you're actually on a schedule."

Another software developer, Matthew, building out his firm's transactional ridesharing platform emphasized again how much economic control firms and platforms have over drivers. Reflecting on the practice of letting drivers go, he stated, "we can just turn them off, there's no HR, there's no firing or hiring, it's just, at the back end we say we don't give them rides anymore, then they're not employed with us. But we never tell them they're fired." Review processes, since different kinds of users are subject to them, might form a kind of mutual reciprocity principle, but they also serve as a non-negotiable 
prerequisite for participation and inclusion in on-demand platforms, unevenly generating the perception of trust and security but with detrimental and punitive effects on certain parties. This 'soft control,' through algorithmically mediated 'information asymmetry' between the platform and the driver (Rosenblat and Stark, 2015), functioned as an attempt to eliminate differences between driver and passenger in the sharing practice, predicated on the "reciprocity principle" of mutual surveillance.

Sharing in this context meant the production of a system of trust that functioned paradoxically both as a supposedly egalitarian "reciprocity principle" between parties but concealed instead a profound inequality between different kinds of users. The quantification of self-policing was framed in a positive light, or at least, as nonnegotiable, as the prerequisite bare minimum for participation and inclusion in ondemand platforms, connoting the production of a supposedly intimate and safe public that "good actor[s] in the system" could build together by reporting on one another's behavior.

\subsection{Shared futures}

Like Eric, who suggested above that sharing in the on-demand economy could herald a new form of socialism, others associated the sharing economy with utopian fantasies about the future. The on-demand economy is characterized, as noted in the introduction, by a paradox as it promises both capitalism and its alternative. This played out often in research subjects' comments about what they thought the on-demand economy offered to society. Research subjects noted the promise of sharing as offering a 'new' mode of participation in capitalist society, or as a 'post-capitalist' fantasy. With this utopian view Craig framed his startup (a crowdsourced financing platform) as "like a bank, kind of like village banking, but modern village banking." Similarly, Mike, commenting on his quasi-transactional platform also drew on the village metaphor,

"we're sort of bringing things back to this village idea back when humanity first started or civilization first started. We didn't really have money and people traded goods and services for one another. So, you know, or they traded favors, [...] if there's an ideal sharing economy it's more like that."

Sharing, as discussed as a form of 'village capitalism' or 'socialism,' associates sharing and the practices it encourages with a form of normative sentimentality, nostalgia for a 
more 'authentic' form of inter-personal economic engagement, and a promise for a new form of social participation based on a universalizing myth about how early human societies originally lived. As anthropologists writing on sharing have noted, these fantasies about an 'original' human society defined by egalitarian and non-reciprocal sharing practices reflects a particularly essentializing hubris that reproduces a colonialist (not to mention inaccurate) imaginary (Schnegg, 2015; Speth, 1990; Widlock, 2013). The utopianism of the sharing discourse re-orients the way we talk about labor and work in the $21^{\text {st }}$ Century, while holding out for a real transformation and hope for alternatives to the capitalist system, or a return to a 'more authentic' set of social relations. These alternatives were associated with making available more time, space, and resources. As Eric put it in relation to his hopes for the ridesharing platform he worked for,

“right now you've got one guy driving to work, and another woman driving to work, they both do a trip from the same place in the morning, they park their cars in the garage, their cars are sitting there all day until $5 \mathrm{pm}$, and then they get in, they drive home, so it's not just like those two could have shared a trip, but it's like that whole time, that car was parked in the garage it could have been driving people around."

For Eric, the benefit of ride sharing in the on-demand economy would be to eventually make more time available for those currently driving separately to work, make parking facilities available for other urban developments, and make cars available that would otherwise be sitting empty in those parking lots. Of course, against this more social interpretation, we could also suggest that this interviewee sought a system in which fixed capital could circulate more effectively and efficiently, in a broader pro-capitalist strategy (Harvey, 1982).

In contract to the quote above, Mike was more skeptical and ambivalent about these possible sharing futures:

"it almost feels like it's building out this promise that technology had of democratizing everything, and making everything free and available, but at the same time sometimes it feels exploitative, and that it's creating this society of the people that can afford to use these services, and the other people that make these services run, that drive your car or deliver your goods or any of this stuff. [...] I'm not sure if it's making the world better, or just accelerating a lot of the inequality."

In contrast with Eric, Mike outlined a possible consequence of the on-demand economy the potential of the further fragmentation of society by divisions of class, a transition 
from a society based on individual ownership to one based on the demand for access (Richardson, 2015). Karl Marx (1976) framed class divisions at their most basic as between those in control of the means of production through private property ownership the capitalist - and those who must make a subsistence living by selling their labor-power to the former - the worker. Mike feared that new class divisions under the sharing rubric might create a circumstance in which the capitalist class can afford to not privately own resources (while still owning the means of production, connoting a decadent, yet minimalist aesthetic) but instead demand access at any moment to others' resources and labor-power - those who make up the new working class. This latter group must invest what little surplus they are able to retain in assets with minimal prospects of appreciation (e.g., automobiles) to support the former for whom on-demand access to others' laborpower, in place of the direct ownership of these resources, is novel. In this view, overt social differences between classes are removed from the public sphere, as the capitalist no longer meets the worker at a physical market to purchase their labor power, conducting said transaction under terms set by a third party platform, through the use of a digital application on a smart phone. This further enhances the illusion of equality between capitalist and worker, who both participate in a mutual fantasy that the demand made by the former in terms of the purchase of the latter's labor power is an inclusive and social form of sharing. On-demand workers constitute, without participating directly in, this digitally mediated form of capitalist exchange.

Sharing discourses hold out on the promise of change to the capitalist mode of production, through an appeal to a more authentic and 'traditional' form of predominantly social (and not economic) relation that encourages workers' complicity in the normalization of flexible labor. While Marx (1976) describes in detail how workers are treated like commodities under industrial capitalism, and Foucault (2008) describes the worker's image of themselves as framed by the rhetoric of 'human capital' under neoliberal forms of reason, on-demand platforms encourage an understanding of commodities and labor as continuous, not distinct. Labor as something 'shared,' rather than sold and purchased in the on-demand economy, becomes metonymic with a form of excessive, and therefore cheap, always-available information. The laborer who chooses not to 'share' their labor is framed as the figure that selfishly or aggressively rejects the 
promise of inclusion in the new better life and community. Sharing creates the conditions for discussing labor as something consumers are entitled to access conveniently and at any moment. The on-demand economy is thus an attempt, and perhaps only an attempt, to create a set of conditions for talking about and understanding labor as something disposable that must respond immediately to the demands of smartphone users.

\section{Conclusion and discussion: shared discourse, sentimental affect}

Proponents of the on-demand economy above, in attempting to treat labor as a ubiquitously available cheap commodity, connect sharing to an economic practice constituted through a particular way of speaking, talking, and performing a disinterested attitude toward labor. In the on-demand economy, discourse and economic practice are inter-related and mutually constitutive phenomena. The sharing discourses discussed here, and the possibility for the devaluation of labor that accompany them, are in broad continuity with the normalization of flexible labor occurring in the United States since the 1970s (Peck, 1992; Theodore, 2016), in particular in the context of new media production (Benner, 2002; Christopherson, 2002). With the sharing discourse, attitudes toward labor in other digital contexts is often oriented toward the justification of lowpaid, on-demand, piece-work, in which workers' disparate geographical contexts, and punitive discouragement by digital platforms undermine workers' possibilities for collective action and progressive changes to their circumstances (Ettlinger, 2016; Irani, 2015; Lehdonvitra, 2016). These insights attest to the relationship between political economy and digital systems (Leszczynski, 2012) and the necessity for further research into the relationships between flexible and precarious work, the conventional troping of work that justifies particular working practices over others, and changing technologies. Rather than collapse all digital forms of work as 'affective' and coterminous (Hardt and Negri, 2000), different circumstances of work may require analysis to be undertaken on a platform-by-platform basis (see Barreneche and Wilkin, 2015) to give attention to how work and the capitalist mode of production are changing with and through digital systems, and alongside the production of working subjectivities, discursive formations, and affective infrastructures.

My contention is not that sharing holds a connotation with the devaluation of 
labor once and for all, for all users, or that the on-demand contractor or other workers passively accept the conditions of this discourse as set unilaterally by proponents of the on-demand economy platforms and firms. I am not making claims here about how contractors or other workers in the on-demand economy view or navigate the sharing discourse. Nor do I claim that software developers are the sole orchestrators of a unilateral sharing discourse imposed upon on-demand economy workers (i.e., not those producing the platforms themselves, but those paid and unpaid workers that include Uber drivers and Airbnb hosts). Though they are not the focus of this study it must be acknowledged that these workers, as well as consumers, and the mainstream media too resist, reify, and reproduce sharing discourses in complex ways. What I present here are some of the various and contradictory ways that one group associated directly with producing on-demand platforms participates in the co-production of the sharing discourse. I claim that sharing, like other forms of discourse, is not meaningless or incidental, or that it can be simply replaced with a term more accurately representing the supposed 'economic reality' of on-demand labor. On-demand and other digital firms and platforms participate in the production of the sharing discourse, which has a real function in the on-demand economy, though not necessarily one that is the same for all users and workers, and not one that is decided in advance. Taking discourse seriously in the context of economic practice means examining how "sentimental politics bridges fantasy and realism precisely insofar as the blatantly artificial register of conventional troping stands as the textual performance of universality itself' (Berlant, 2008, page 36). Pointing out the blatant artificiality of sharing (as some popular commentators have done) misses the point, and does little to deflect the power of the sharing discourse, since sharing offers subjects comfort and solace through its "conventional troping" of the ordinary. Sharing, as a normative script for narrating on-demand work (whether successful or not), is a strategy for talking about work in sentimental terms of social relation and participation in neoliberal capitalism. This demonstrates the imbrication of discourse and economic practices, and shows how neoliberal capitalism, far from being associated with the production and perpetuation of 'flat affects,' (e.g., Harvey, 2005) can be more accurately thought of as directly constitutive of the production of new sets of social meanings and collective structures of feeling (Anderson, 2015; Konings, 2015) though ones in which 
attrition and repair are ambivalently interwoven and may a single, indistinguishable process (Berlant, 2007).

This analysis points to the importance of paying closer attention to how labor relations are reproduced, by whom, in which times and spaces, and under what circumstances (Peck, 2002), and how those relations connect up with supposedly 'noneconomic' spheres. How labor is discussed and narrated relates closely to how labor is understood and valued (Weeks, 2011). At its broadest, aligning a couchsurfer and Uber driver, or a Yelp reviewer and AirBnB host as participating in a 'sharing economy' elides important distinctions between these different subjects, and obfuscates the laboring contents of the latter pairing, while failing to account for how digital systems that claim to produce new social relations, community, and inclusion, also constitute economic performances. This elision of different laboring activities through the sharing discourse is strategic, not incidental. The desire to share, and to form an economic vocabulary around sharing as a practice, is a contested attempt by some proponents of on-demand activity to reify economic transaction and private ownership as essential to 'life' as such, and situate personal labor-power as an abundant resource that appropriately virtuous and altruistic individuals should make available to the demands of others as the basis of an authentic and just society. To share without abandon as a confessional practice, as an attempt to be known and knowable, to objectify oneself as exchangeable and to relentlessly partake in exchange becomes in this discourse a form of social participation, an aggressive and opportunistic attempt to solidify bonds of trust with others, or to orient oneself toward to 'right' way of behaving as a economic corrective to a positive 'good life' fantasy.

\section{References}

Ahmed, S., 2010. The Promise of Happiness. Duke University Press, Durham.

Amoore, L., 2011. Data derivatives: on the emergence of a security risk calculus for our times. Theory Culture \& Society. 28 (6), 24-43.

Anderson, B., 2015. Neoliberal affects. Progress in Human Geography. OnlineFirst.

Belk, R., 2014a. Sharing Versus Pseudo-Sharing in Web 2.0. Anthropologist. 18 (1), 723.

Belk, R., 2014b. You are what you can access: Sharing and collaborative consumption 
online. Journal of Business Research. 67 (8), 1595-1600.

Banning, M. E., 2016. Shared englanglements - Web 2.0, info-liberalism \& digital sharing. Information, Communication \& Society. 19 (4), 489-503.

Bathelt, H. and Turi, P., 2011. Local, global and virtual buzz: The importance of face-toface contact in economic interaction and possibilities to go beyond. Geoforum. $42,520-529$.

Benner, C., 2002. Work in the New Economy: Flexible Labor Markets in Silicon Valley. Blackwell, Oxford.

Barnett, C., 2005. The consolations of 'neoliberalism.' Geoforum. 36 (1), 7-12.

Barreneche, C. and Wilkin, R., 2015. Platform specificity and the politics of location data extraction. European Journal of Cultural Studies. 18 (4-5), 497-513.

Benkler, Y., 2004. Sharing nicely: on sharable goods and the emergence of sharing as a modality of economic production. The Yale Law Journal. 114 (2), 273-358.

Benkler, Y., 2006. The Wealth of Networks: How Social Production Transforms Markets and Freedom. Yale University Press, New Haven.

Berlant, L., 2007. Slow death (sovereignty, obesity, lateral agency). Critical Inquiry. 33 (4), 754-780.

Berlant, L., 2008. The Female Complaint: The Unfinished Business of Sentimentality in American Culture. Duke University Press, Durham.

Berlant, L., 2011. Cruel Optimism. Duke University Press, Durham.

Brown, W., 2015. Undoing the Demos: Neoliberalism's Stealth Revolution. Zone Books, New York.

Butler, J., 1990. Gender Trouble. Routledge, London.

Cairnes, K., 2013. The subject of neoliberal affects: rural youth envision their future. The Canadian Geographer, 57 (3), 337-344.

Castree, N., 2006. From neoliberalism to neoliberalisation: consolations, confusions, and necessary illusions. Environment and Planning A. 38 (1), 1-6.

Cheney-Lippold, J., 2011. A new algorithmic identity: soft biopolitics and the modulation of control. Theory, Culture \& Society. 28 (6), 164-181.

Christopherson, S., 2002. Project work in context: regulatory change and the new geography of media. Environment and Planning A. 34 (11), 2003-2015. 
Christopherson, S., 2008. Beyond the self-expressive creative worker: an industry perspective on entertainment media. Theory, Culture \& Society. 25 (7-8), 73-95.

Cockayne, D. G., 2016. Affect and value in critical examinations of the production and 'prosumption' of big data. Big Data \& Society. 3 (2), 1-11.

Coe, N., 2013. Geographies of production III: making space for labour. Progress in Human Geography. 37 (2), 271-284.

Deleuze, G., 1992. Postscript on the societies of control. October. 59, 3-7.

Ettlinger, N., 2003. Cultural economic geography and the relationship and microspace approach to trusts, rationalities, networks, and change in collaborative workspaces. Journal of Economic Geography. 3 (2), 145-171.

Ettlinger, N., 2014. The Openness Paradigm. New Left Review. 89, 89-100.

Ettlinger, N., 2016. The governance of crowdsourcing: Rationalities of a new exploitation. Environment and Planning A.

Foucault, M., 1972. The Archaeology of Knowledge. Vintage, New York.

Foucault, M., 1978. The History of Sexuality, Volume 1. Vintage, New York.

Foucault, M., 1981. The Order of Discourse. In: Young, R. (Ed.), Untying the Text: A Post-Structuralist Reader. Routledge \& Kegan Paul, London, pp. 57-78.

Foucault, M., 2008. Lectures at the Collège de France 1978-1979, The Birth of Biopolitics. Picador, New York.

Fuchs, C., 2010. Labor in informational capitalism on the internet. The Information Society. 26 (3), 179-196.

Fuchs, C., 2014. Digital Labour and Karl Marx. Routledge, New York and London.

Gibson-Graham, J. K., 1996. The End Of Capitalism (As We Knew It): A Feminist Critique of Political Economy. Blackwell, London.

Gile, E. and Handcock, M., 2010. Respondent-driven sampling: an assessment of current methodology. Sociological Inquiry. 40 (1), 285-327.

Gill, R. and Pratt, A., 2008. In the social factory? Immaterial labor, precariousness and cultural work. Theory, Culture \& Society. 25 (7-8), 1-30.

Grabher, G. and Ibert, O., 2014. Distance as asset? Knowledge collaboration in hybrid virtual communities. Journal of Economic Geography. 14 (1), 97-123.

Gregg, M., 2015. The doublespeak of the gig economy. The Atlantic. Available at: 
http://www.theatlantic.com/business/archive/2015/09/gig-economy-doublespeaknew-labor/404779/ (accessed: November 17 2015).

Hacklay, M., 2013. Neogeography and the delusion of democratization. Environment and Planning A. 45 (1), 55-69.

Hardt, M. and Negri, A., 2000. Empire. Harvard University Press, Cambridge.

Harvey, D., 1982. The Limits to Capital. London, Verso.

Harvey, D., 2005. A Brief History of Neoliberalism. Oxford University Press, Oxford.

Irani, L., 2015. Difference and dependence among digital workers: the case of Amazon Mechanical Turk. South Atlantic Quarterly. 114 (1), 225-234.

John, N. A., 2012. Sharing and web 2.0: the emergence of a keyword. New Media \& Society. 15 (2), 167-182.

John, N. A., 2013. The social logics of sharing. The Communication Review. 16 (3), 113131.

John, N. A. and Sützl, W., 2016. The rise of 'sharing' in communication and media studies. Information, Communication \& Society. 19 (4), 437-441.

Joseph, M., 2002. Against the Romance of Community. University of Minnesota Press, Minneapolis.

Joseph, M., 2014. Debt to Society: Accounting for Life under Capitalism. University of Minnesota Press, Minneapolis.

Konings, M., 2015. The Emotional Logic of Capitalism: What Progressives Have Missed. Stanford University Press, Stanford.

Larner, W., 2003. Neoliberalism? Environment and Planning D: Society and Space. 21 (5), 509-512.

Larner, W., and Walters, W., 2004. Globalization as governmentality. Alternatives. 29 (5), 495-514.

Lawson, V., 2010. Reshaping economic geography? Producing spaces of inclusive development. Economic Geography. 86 (4), 351-360.

Lehdonvitra, V., 2016. Algorithms that divide and unite: delocalization, identity, and collective action in 'microwork.' In: Flecker, J. (Ed.), Space, Place, and Global Digital Work. Palgrave-Macmillan, London.

Leszczynski, A., 2012. Situating the geoweb in the political economy. Progress in Human 
Geography. 36 (1), 72-89.

Leyshon, A., 2007. Scary monsters? Software formats, peer-to-peer networks, and the spectre of the gift. Environment and Planning D: Society and Space. 21 (5), 533558.

Marazzi, C., 2007. Capital and Language: From the New Economy to the War Economy. Semiotext(e), Los Angeles.

Marx, K., 1976. Capital: A Critique of Political Economy, Volume 1. Penguin, London.

Massey, D., 2004. Geographies of responsibility. Geografiska Annaler: Series B, Human Geography. 86 (1), 5-18.

McDowell, L., 1997. Capital Culture: Gender at Work in the City. Blackwell, Oxford.

McDowell, L., 2009. Interviewing: Fear and liking in the field. In: DeLyser, D., Herbert, S., Aitken, S., Crang, M. and McDowell, L. (Eds.) The SAGE Handbook of Qualitative Geography. Sage, London, pp. 156-171.

McDowell, L. and Christopherson, S., 2009. Transforming work: new forms of employment and their regulation. Cambridge Journal of Regions, Economy and Society. 2 (3), 335-342.

McDowell, L. and Dyson, J., 2011. The other side of the knowledge economy:

'reproductive' employment and affective labours in Oxford. Environment and Planning A. 43 (9), 2186-2201.

Murphy, J. T., 2006. Building trust in economic space. Progress in Human Geography. 30 (4), 427-450.

Neo, H., 2010. Geographies of subcontracting. Geography Compass. 4 (8), 1013-1034.

Ong, A., 2007. Neoliberalism as mobile technology. Transactions of the Institute of British Geographers. 32 (1), 3-8.

Peck, J., 1992. Labor and agglomeration: control and flexibility in local labor markets. Economic Geography. 68 (4), 325-347.

Peck, J., 2002. Labor, zapped/growth, restored? Three moments of neoliberal restructuring in the American labor market. Journal of Economic Geography. 2 (2), 179-220.

Peck, J., 2004. Geographies of public policy: constructs of neoliberalism. Progress in Human Geography. 28 (3), 392-405. 
Peck, J., 2005. Economic sociologies in space. Economic Geography. 81 (2), 129-175.

Peck, J., and Tickell, A., 2002. Neoliberalizing space. Antipode. 34 (3), 380-404.

Povinelli, E., 2011. Economies of Abandonment: Social Belonging and Endurance in Late Liberalism. Duke University Press, Durham.

Richardson, L., 2015. Performing the sharing economy. Geoforum. 67, 121-129.

Rifkin, J., 2014. The Zero Marginal Cost Society: The Internet of Things, the Collaborative Commons and the Eclipse of Capitalism. St. Martin's Press, New York.

Rosenblat, A. and Stark, L., 2015. Uber's drivers: information asymmetries and control in dynamic work. Data \& Society Research Institute. Available at: http://papers.ssrn.com/sol3/papers.cfm?abstract_id=2686227 (accessed: November 17 2015).

Schnegg, M., 2015. Reciprocity on demand: Sharing and exchanging food in Northwestern Namibia. Human Nature. 26 (3), 313-330.

Schor, J., 2015. The sharing economy: reports from stage one. Unpublished manuscript. Available at: http://www.bc.edu/content/dam/files/schools/cas_sites/sociology/pdf /TheSharingEconomy.pdf (accessed: November 30 2015).

Sin, C. H., 2003. Interviewing in "place": the socio-spatial construction of interview data. Area. 35 (3), 305-312.

Speth, J. D., 1990. Seasonality, resource stress, and food sharing in so-called 'egalitarian' foraging societies. Journal of Anthropological Archaeology. 9 (2), 148-188.

Storper, M. and Venables, A. J., 2004. Buzz: face-to-face contact and the urban economy. Journal of Economic Geography 4 (4), 351-370.

Sützl, W., 2014. The anti-economy of sharing. Else Art Journal. 0, 122-140.

Theodore, N., 2016. Worlds of work: Changing landscapes of production and new geographies of opportunity. Geography Compass. 10 (4), 179-189.

Turner, F., 2006. From Counterculture to Cyberculture: Stewart Brand, the Whole Earth Network, and the Rise of Digital Utopianism. University of Chicago Press, Chicago. Waite, L., 2009. A place and space for a critical geography of precarity? Geography Compass. 3 (1), 412-433.

Weeks, K., 2011. The Problem with Work: Feminism, Marxism, Antiwork Politics and 
Postwork Imaginaries. Duke University Press, Durham.

Widlock, T., 2013. Sharing: Allowing other to take what is valued. HAU: Journal of Ethnographic Theory. 3 (2), 11-31.

Zelizer, V., 2005. The Purchase of Intimacy. Princeton University Press, Princeton.

Zervas, G., Proserpio, D. and Byers, J. W., 2014. The rise of the sharing economy: estimating the impact of Airbnb on the hotel industry. Boston University School of Management Research Paper No. 2013-16. Available at: http://papers.ssrn. com/sol3/Papers.cfm?abstract_id=2366898 (accessed: November 17 2015). 